\title{
Generation of Fibrinolytic Activity by \\ Infusion of Activated Protein C into Dogs
}

\author{
Philip C. Comp and Charles T. Esmon, Section of Experimental Pathology \\ and Medicine, University of Oklahoma Health Sciences Center, Oklahoma \\ City, Oklahoma 73190
}

A B S T R A C T Bovine-activated protein C, administered intravenously to dogs, increases the rate of lysis of whole blood clots. Protein C, bovine prothrombin, and diisopropylfluorophosphate-inactivated protein $\mathrm{C}_{\mathrm{a}}$ do not increase the rate of lysis. Repeated infusions of protein $\mathrm{C}_{\mathrm{a}}$ sustain rapid blood clot lysis, but neither elevate circulating fibrin-split products nor decrease circulating plasminogen levels. The administration of protein $\mathrm{C}_{\mathrm{a}}$ results in the elevation of the levels of lysineadsorbable plasminogen activator activity in the plasma. When partially purified concentrates of this activator are added to normal dog blood at the levels seen following protein $C_{a}$ injection, the rate of clot lysis is similar to that seen after protein $\mathrm{C}_{\mathrm{a}}$ injection. The addition of protein $\mathrm{C}_{\mathrm{a}}$ to citrated whole blood in vitro, with the subsequent neutralization of protein $\mathrm{C}_{\mathrm{a}}$ with antibodies, results in increased rates of lysis when plasma made from the treated blood is reinjected into the animal. The generation of fibrinolytic activity is dependent on both cellular and plasma components of blood. A model of protein $\mathrm{C}_{\mathrm{a}}$ fibrinolytic activity has a minimum of two components: a secondary messenger formed by protein $\mathrm{C}_{\mathrm{a}}$ action on blood cells and plasma, and the subsequent appearance of plasminogen activator in the animal in response to that messenger.

\section{INTRODUCTION}

Protein $\mathrm{C}$ is a vitamin $\mathrm{K}$-dependent plasma protein and is the zymogen of a serine protease, activated protein C. Unlike the vitamin K-dependent clotting factors, activated protein $\mathrm{C}$ inhibits clot formation. This anticoagulant activity appears to involve the selective inactivation of Factors V (Va) (1) and VIII (VIIIa) (2). Anticoagulant activity is dependent on the proteolytic active site because incorporation of diisopropylphosphate into the active site totally blocks this activity (3).

Received for publication 18 May 1981 and in revised form 13 July 1981.
Evidence for the activation of protein $\mathrm{C}$ in vivo has recently been presented by Marlar and Griffin (4) who showed that a group of patients lacking an inhibitor to activated protein $\mathrm{C}$ exhibited simultaneous Factor VIII and Factor V deficiency. We have now shown the presence of an endothelial cell surface cofactor for thrombin-catalyzed protein $\mathrm{C}$ activation that accelerates the thrombin-catalyzed activation of protein $\mathrm{C}$ at least 20,000 -fold $(5,6)$. These observations provide evidence for protein $\mathrm{C}$ activation in humans and provide a plausible mechanism by which this activation can occur.

In addition to its function as an anticoagulant, activated protein $\mathrm{C}$ has been shown by Zolton and Seegers $(7,8)$ to enhance fibrinolysis, at least in part, by lowering the levels of fibrinolytic inhibitors. Our studies (9) have confirmed that fibrinolytic activity can be generated both in vivo and in vitro in response to activated protein $\mathrm{C}$. We have recently described a quantitative method for using lysine-agarose to assay plasminogen activator levels (10). We have now used this assay to further characterize the in vivo fibrinolytic state induced by activated protein $\mathrm{C}$.

\section{METHODS}

Reagents. Bovine blood was the generous gift of the Cornett Packing Company, Oklahoma City, Okla. QAESephadex Q-50, SP-Sephadex C-50, porcine heparin grade II, and soybean trypsin inhibitor were purchased from Sigma Chemical Co., St. Louis, Mo. D-valine-leucine-lysine-pnitroanilide (S2251) was purchased from Ortho Pharmaceuticals, Raritan, N. J. Benzamidine $\mathrm{HCl}$ was purchased from Aldrich Chemical Co., Milwaukee, Wis. Acrylamide of electrophoresis grade was purchased from Eastman Laboratory and Specialty Chemicals, Rochester, N. Y. All other reagents were of the highest grade commercially available.

Preparation of affinity columns. Lysine (11) and heparin (12) were coupled to Biogel agarose A 15 (Bio-Rad Laboratories, Richmond, Calif.) following cyanogen bromide (CNBr) activation (13).

Preparation of proteins. All proteins were of bovine origin. Protein $C(14,15)$ and prothrombin (16) were isolated by published methods. Thrombin was prepared by activation 
of prothrombin with Factor Xa, Factor Va, phospholipid, and $\mathrm{Ca}^{++}$as described (16). Bovine and canine plasminogen were prepared by the method of Deutsch and Mertz (11).

Protein C $(20 \mathrm{mg}, 3 \mathrm{mg} / \mathrm{ml})$ was activated with bovine thrombin ( $1 \mathrm{mg}, 0.15 \mathrm{mg} / \mathrm{ml}$ ) in $2 \mathrm{mM}$ Tris buffer, $\mathrm{pH} 7.4$, containing $50 \mathrm{mM} \mathrm{NaCl}$ at $4^{\circ} \mathrm{C}$ for $16 \mathrm{~h}$. The activation mixture was then brought to $\mathrm{pH} 6.0$ by the addition of $2(\mathrm{~N}$ morpholine) ethane sulfonic acid to a final concentration of $20 \mathrm{mM}$. The mixture was then chromatographed on a 0.9 $\times 60 \mathrm{~cm}$ sulfopropyl Sephadex C-50 column equilibrated in $50 \mathrm{mM} \mathrm{NaCl}, 1 \mathrm{mM}$ benzamidine, $20 \mathrm{mM} 2(N$-morpholine $)$ ethane sulfonic acid, $\mathrm{pH}$ 6.0. Activated protein $\mathrm{C}$ was not retained. Fractions containing protein $\mathrm{C}_{\mathrm{a}}$ were then chromatographed on a column of QAE Sephadex Q-50 $(0.9 \mathrm{~cm}$ $\times 2 \mathrm{~cm}$ ), and the column washed with $0.1 \mathrm{M} \mathrm{NaCl}, 20 \mathrm{mM}$ Tris $\mathrm{HCl}, 1 \mathrm{mM}$ benzamidine $\mathrm{HCl}, \mathrm{pH}$ 7.4. The protein $\mathrm{C}_{\mathrm{a}}$ was then eluted from the column with a linear $\mathrm{NaCl}$ gradient (0.1-0.7 M) in the Tris-benzamidine buffer. Activated protein $\mathrm{C}$ anticoagulant activity was monitored by determining the prolongation of a Factor Xa clotting time (17).

Animal studies. Mongrel dogs were anesthetized with sodium nembutal administered intravenously. Protein solutions were administered by injection into a foreleg vein. Blood samples were withdrawn via a 2 -in 18-gauge intravenous catheter (Becton-Dickinson \& Co., Rutherford, N. J.) inserted into the external jugular vein. The catheter was occluded with a 2-in Safedwel catheter (Becton-Dickinson \& Co.) when not in use. The catheter was cleared by aspirating and discarding $2-3 \mathrm{ml}$ of blood before samples were drawn.

Fibrinolysis studies in whole blood clots. Whole blood $(2.5 \mathrm{ml})$ was collected, added to a $17 \times 100-\mathrm{mm}$ polystyrene tube containing $280 \mu \mathrm{l}$ of $3.8 \%$ citrate, $\mathrm{pH} 5.5$, and mixed immediately on a Vortex mixer. To this was added $10 \mu \mathrm{g}$ ${ }^{125}$ I-human fibrinogen with a specific activity of $\sim 167 \mu \mathrm{Ci} / \mathrm{mg}$ and the blood again mixed. The blood was clotted with $5 \mathrm{U}$ bovine thrombin in $100 \mu$ l of $0.15 \mathrm{M} \mathrm{NaCl}, 20 \mathrm{mM}$ Tris $\mathrm{HCl}$, pH 7.4. The thrombin was added while vortexing the blood. The blood was allowed to clot at room temperature for $5 \mathrm{~min}$ and then the clot was freed from the wall of the tube by rimming the clot with a round wooden applicator stick. The clots were then incubated in a $37^{\circ} \mathrm{C}$ water bath and at 30 min, $1 \mathrm{~h}$, and hourly intervals thereafter, 100- $\mu$ l samples of serum were withdrawn from around the clot and placed in 400- $\mu$ l plastic microcentrifuge tubes (Bio-Rad Laboratories). The tubes were centrifuged for 5 min in a Beckman microfuge B. $30 \mu \mathrm{l}$ serum was then removed from above the pellet of shed erythrocytes, placed in a Biovial, and ${ }^{125}$ I-fibrin-split product content was determined by counting the sample in a Beckman gamma counter. Visible clot lysis was monitored by gently tipping the tubes at hourly intervals. Lysis was judged to be complete when the organized clot was no longer visible.

Plasminogen activator assay. Plasminogen activator activity in canine plasma was measured using lysine-agarose and bovine fibrin agar plates as described for human plasma (10). Using this method, canine plasma was passed through lysine-agarose columns and the adsorbed plasminogen activator activity was eluted from the columns with ammonium thiocyanate-containing buffer. Plasminogen activator activity was then quantitated by measuring the conversion of plasminogen to plasmin on bovine fibrin agar plates.

Preparation of concentrated plasminogen activator. Concentrated preparations of lysine-adsorbable plasminogen activator were made from blood obtained 5 min after the intravenous injection of $5 \mu \mathrm{g}$ protein $\mathrm{C}_{\mathrm{a}}$ per milliter plasma volume. Benzamidine and EDTA were added to citrated canine plasma as described (10), and $10 \mathrm{ml}$ of plasma was chromatographed on a $0.9 \times 10-\mathrm{cm}$ lysine-agarose column.
After washing, the plasminogen activator was eluted from the column as described at a rate of $3 \mathrm{ml} / \mathrm{h}$. The activator activity was measured on fibrin agar plates and fractions containing the activator were pooled. The pool was placed in dialysis tubing and the tubing covered with dry Sephadex G-50 at $4^{\circ} \mathrm{C}$. After the activator activity was concentrated 6-10fold, the sample was removed from the dialysis bag and stored at $-80^{\circ} \mathrm{C}$ until used. Aliquots were dialyzed for $4 \mathrm{~h}$ at $4^{\circ} \mathrm{C}$ immediately before addition to normal canine blood.

Preparation and assay of anti-bovine protein $C$ antibodies. Rabbits were innoculated with protein $\mathbf{C}$ in Freund's complete adjuvant at weekly intervals for $3 \mathrm{wks}$ and then with protein C in Freund's incomplete adjuvant 1 wk later. Serum was obtained after the final innoculation and the IgG fraction purified. The IgG fraction was then concentrated by ammonium sulfate precipitation and dialyzed against $0.15 \mathrm{M}$ $\mathrm{NaCl}, 0.02 \mathrm{M}$ Tris- $\mathrm{HCl}, \mathrm{pH} \mathrm{7.4}$. The IgG was then chromatographed over Ultrogel AcA34 in the same buffer that removed all contaminating plasminogen activator activity, as assayed by incubation of the IgG with plasminogen on fibrin agar plates.

The antiprotein C-IgG was assayed using the Xa-one stage assay. Under the conditions of this assay, the control clotting time of $28 \mathrm{~s}$ was prolonged to $>80 \mathrm{~s}$ by the addition of $5 \mu \mathrm{g}$ protein $\mathrm{C}_{\mathrm{a}}$ per milliter of normal canine plasma. The addition of $40 \mu \mathrm{l}$ of antiprotein C-IgG $(6 \mathrm{mg} / \mathrm{ml})$ to $1 \mathrm{ml}$ of canine plasma containing $5 \mu \mathrm{g}$ protein $\mathrm{C}_{\mathrm{a}}$ completely corrected the prolongation of the $\mathrm{Xa}$ clotting time.

Preparation of canine plasma and washed blood cells. Citrated plasma was prepared from citrated blood by centrifugation at $1000 \mathrm{~g}$ for $10 \mathrm{~min}$ at $25^{\circ} \mathrm{C}$. Washed blood cells were prepared by resuspension of the cellular sediment in 5 vol of Hanks' HEPES buffer containing 1 part $3.8 \%$ sodium citrate, $\mathrm{pH} 5.5$, per 9 parts buffer. The resuspended cells were centrifuged $5 \mathrm{~min}$ at $1,000 \mathrm{~g}$ and the washing was repeated. The sedimented cells were resuspended with Hanks' HEPES buffer-containing citrate to the original blood volume before use.

Estimation of plasma plasminogen activator molecular weight. 200- $\mu$ l samples of lysine-adsorbable plasminogen activator containing $0.5 \mathrm{NH}_{4} \mathrm{SCN}$ were made $0.1 \%$ in sodium dodecyl sulfate (SDS) at room temperature and electrophoresed at $50 \mathrm{mV}$ at $25^{\circ} \mathrm{C}$ on $10 \%$ acrylamide gels containing $0.1 \%$ SDS (18). Gels were cut into $2-\mathrm{mm}$ slices, crushed with a glass rod, and eluted with $200 \mu \mathrm{l}$ of $20-\mathrm{mM}$ Tris buffer, $\mathrm{pH} 7.4$, containing $10 \mathrm{mg} / \mathrm{ml}$ bovine albumin, $1 \mathrm{mg} / \mathrm{ml}$ bovine plasminogen, and $0.15 \mathrm{M} \mathrm{NaCl}$ for $2 \mathrm{~h}$ at $4^{\circ} \mathrm{C}$. The plasmin substrate, S-2251 (30 $\mu$ l of $3 \mathrm{mM} \mathrm{S-2251)}$ was added and the mixture incubated $2 \mathrm{~h}$ at $37^{\circ} \mathrm{C}$. The reaction was stopped by the addition of $400 \mu \mathrm{l}$ of $50-\mathrm{mM}$ acetic acid. The hydrolysis of the $\mathrm{S}-2251$ was then quantified by monitoring absorption at $405 \mathrm{nM}$ after centrifugation to remove gel fragments.

\section{RESULTS}

\section{Effect of activated protein C on whole blood clot} lysis. The intravenous administration of activated protein $\mathrm{C}$ resulted in an increase in the rate at which whole blood clots lysed (Fig. 1). Whole blood clots made from blood drawn 5 min after the administration of $3 \mu \mathrm{g}$ protein $\mathrm{C}_{\mathrm{a}}$ per milliter dog plasma volume released ${ }^{125}$ I-fibrin-split products more rapidly than clots formed from blood before protein $\mathrm{C}_{\mathrm{a}}$ injection. The rate of clot lysis gradually decreased after the injection of protein $C_{a}$ and by 35-40 min, had reached preinjection levels. The addition of the same levels of protein $C_{a}$ in 


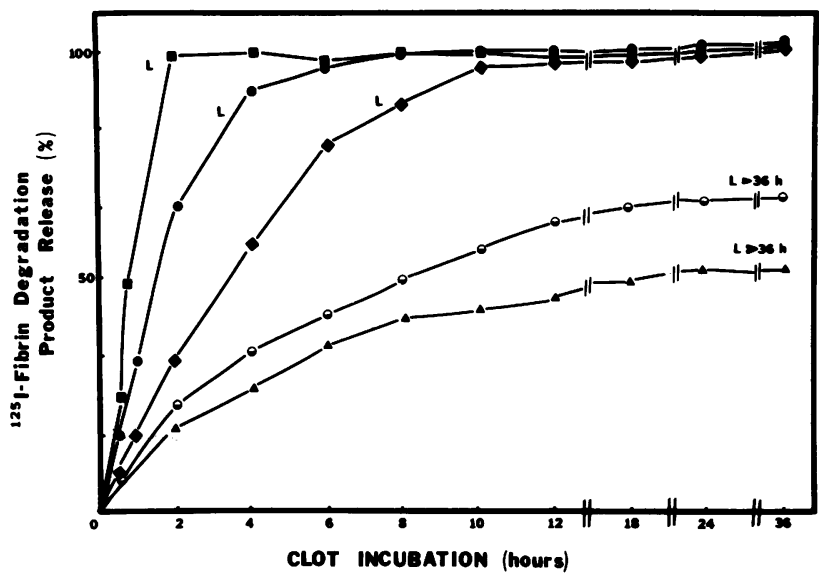

FIGURE 1 Effect of protein $\mathrm{C}_{\mathrm{a}}$ in vitro and in vivo on whole blood clot lysis. The release of ${ }^{125} \mathrm{I}$-fibrin-split products is shown from clots made from blood drawn before $(\Delta)$, at $5(\square)$, $10(\Theta)$, and $20 \mathrm{~min}(\diamond)$ after the intravenous injection of $3 \mu \mathrm{g}$ protein $\mathrm{C}_{\mathrm{a}} / \mathrm{ml}$ dog plasma. Release of fibrin-split products from a clot formed from blood that had the same level of protein $\mathrm{C}_{\mathrm{a}}$ added in vitro is shown $(\theta)$. The time at which complete visible clot lysis occurred is indicated $(L)$ on each curve. Visible lysis did not occur in the preinjection sample or the in vitro addition sample in $36 \mathrm{~h}$. Similar results were obtained with three other dogs.

vitro caused a small, but reproducible increase in the rate of clot lysis. Visible clot lysis correlated with the release of fibrin-split products. Complete lysis of the clots made from blood drawn 5 min after protein $\mathrm{C}_{\mathrm{a}}$ injection occurred 60-80 min after thrombin addition. The clots made before protein $\mathrm{C}_{\mathrm{a}}$ injection, or by the addition of protein $\mathrm{C}_{\mathrm{a}}$ in vitro took longer than $36 \mathrm{~h}$ to lyse. Addition of equivalent levels of protein $C_{a}$ to unanticoagulated blood in vitro gave an increase in the rate of lysis similar to that seen by addition of protein $C_{a}$ to citrated blood (data not shown).

The fibrinolytic response of dogs to protein $\mathrm{C}_{\mathrm{a}}$ administration was found to follow a positive doseresponse curve (Fig. 2). All dogs had a measurable response to $0.5 \mu \mathrm{g}$ protein $\mathrm{C}_{\mathrm{a}} / \mathrm{ml}$. There was an increase in the rate of lysis of the postprotein $\mathrm{C}_{a}$ clots as the in vivo dose of protein $C_{a}$ was increased. One dog was given $10 \mu \mathrm{g}$ protein $\mathrm{C}_{a}$ per milliliter plasma volume. The clots made following this dose completely dissolved in 35-40 min and demonstrated an 18-fold increase in ${ }^{25} \mathrm{I}$-fibrin-degradation product release.

We wished to determine if the fibrinolytic response seen after protein $C_{a}$ injection was specific for activated protein $\mathrm{C}$ or whether class-similar proteins could produce the same response. The proteins selected were bovine prothrombin, diisopropylfluorophosphage, inhibited protein $\mathrm{C}_{\mathrm{a}}$, and the zymogen, protein C. A control injection of saline was also run. Only the protein $\mathrm{C}_{\mathrm{a}}$ increased the rate of clot lysis significantly above preinjection rates.

The effect of repeated infusions of protein $C_{a}$ on fibrinolysis in the dog was also examined. Repeated doses of protein $\mathrm{C}_{\mathrm{a}}$ were administered at 30 -min intervals for 5 h. (Fig. 3). An increased rate of clot lysis was observed and sustained over the 5 -h period. When the infusions were stopped, the rate of clot lysis returned to control levels. Plasminogen levels did not fall during the 5-h period, suggesting that plasminogen was not being converted to plasmin in the circulation. There was no change in the platelet count, suggesting that a condition like disseminated intravascular coagulation was not initiated by the protein $\mathrm{C}_{\mathrm{a}}$. Fibrin-split products in the plasma, as detected by staphylococcal agglutination were not elevated and remained $\leq 10$ $\mu \mathrm{g} / \mathrm{ml}$. This suggested that neither fibrinogen nor fibrin was being degraded.

No change occurred in the animal's systolic, diastolic, or mean arterial blood pressures during the experiment, nor did body temperature, pulse, or respiratory rate change. These findings suggested that the mechanism by which protein $\mathrm{C}_{\mathrm{a}}$ increased fibri-

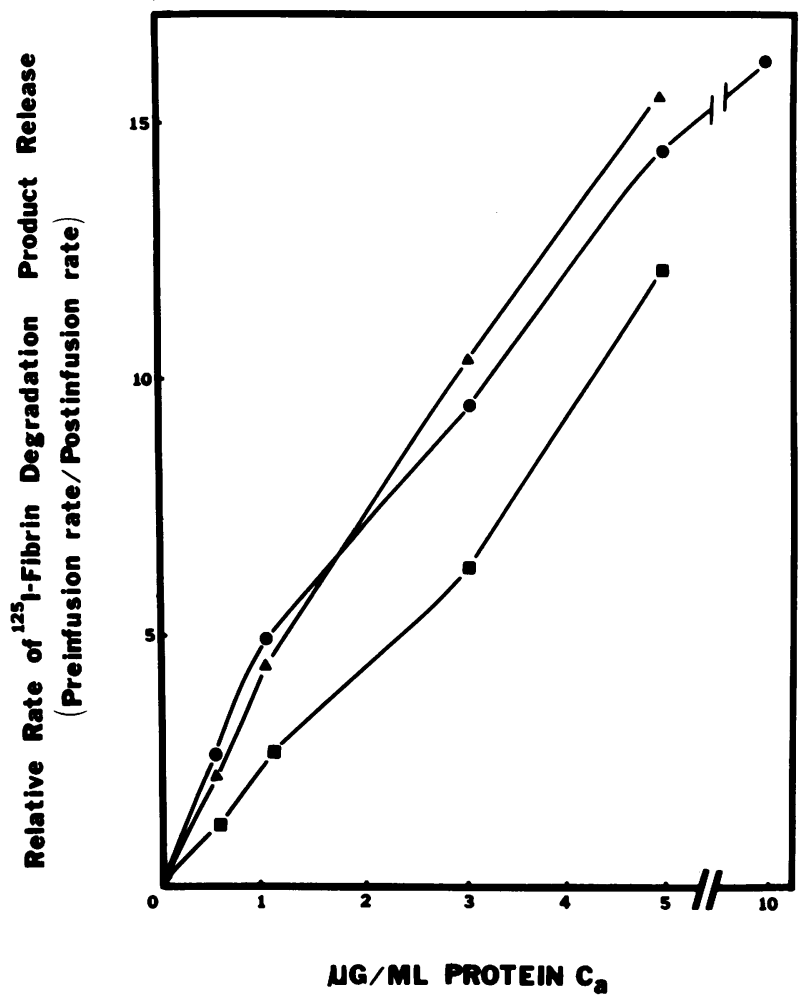

FIGURE 2 Change in the relative rate of fibrin split product release as a function of increasing doses of protein $\mathrm{C}_{a}$ given intravenously. Three mongrel dogs were given increasing doses of protein $C_{a}$ intravenously on four successive days and rate of lysis of clots formed $5 \mathrm{~min}$ after protein $\mathrm{C}_{a}$ administration was compared to the rate of lysis before protein $\mathrm{C}_{\mathrm{a}}$ administration. The relative rate of fibrin-split product release was calculated by dividing the time required for $50 \%$ release of fibrin-split products from the preprotein $\mathrm{C}_{\mathrm{a}}$ control clots by the time required for $50 \%$ release from the postprotein $\mathrm{C}_{\mathrm{a}}$ clots. 


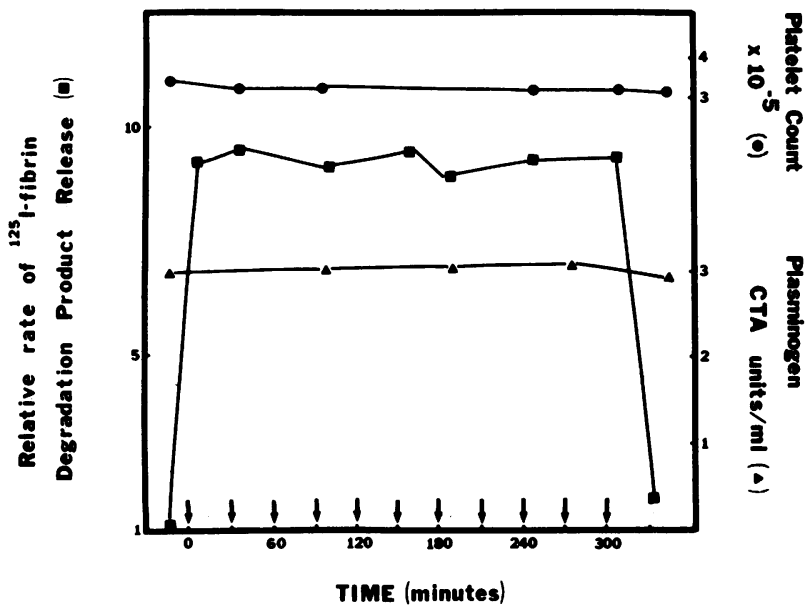

Figure 3 Effect of repeated infusions of protein $C_{a} . A$ dog was infused with $3 \mu \mathrm{g}$ protein $C_{a}$ per milliliter plasma volume at 30-min intervals. The relative rate of ${ }^{125} \mathrm{I}$-fibrin-split product release was monitored $(\boldsymbol{\square})$. Plasminogen levels $(\boldsymbol{\Delta})$ and platelet counts $(O)$ are shown. Each dose of protein $C_{a}$ was given over a 20 -s period. Arrows indicate protein $C_{a}$ infusions. A second animal showed similar results over a 180-min experimental period:

nolytic activity did not involve the release of pyrogens in the blood or production of systemic shock or anaphylaxis. The dog used in this experiment showed no evidence of bleeding during or after the experiment at venipuncture sites. The animal's hematocrit re- mained stable during and after the experiment, suggesting that internal hemorrhage did not occur.

Neutralization of protein $C_{a}$ before clot formation. As noted above, optimal lytic response required intravenous infusion of protein $C_{a}$. Addition of equivalent levels of protein $\mathrm{C}_{\mathrm{a}}$ to citrated blood in vitro gave a comparatively small increase in the rate of clot lysis. This suggested that protein $\mathrm{C}_{a}$, itself, might not be necessary in the clotted blood for the enhancement of lysis to occur. To examine this possibility, we administered protein $\mathrm{C}_{\mathrm{a}}$ intravenously to a dog, drew blood from the animal, and then added sufficient rabbit IgG directed against protein $C$ to neutralize the protein $\mathrm{C}_{\mathrm{a}}$ (Fig. 4). The dog blood treated with the IgG had a rate of clot lysis very similar to the untreated blood. The IgG did not affect the rate of lysis of preprotein $C_{a}$ control blood clots. This suggested that protein $\mathrm{C}_{\mathrm{a}}$ was not having a direct effect in the formed clot but in the circulation.

Effect of protein $C_{a}$ on circulating lysine-adsorbable plasminogen activator levels. Because protein $\mathrm{C}_{\mathrm{a}}$ did not cause clot lysis directly, we examined the canine plasma to determine if plasminogen activator activity was generated as a result of protein $C_{a}$ injection. Specifically, we looked for the appearance of lysineadsorbable plasminogen activator activity in the dog's plasma. Radcliffe and Heinze (19) have found that human lysine-adsorbable plasminogen activator activity increases after exercise and we (10) have found

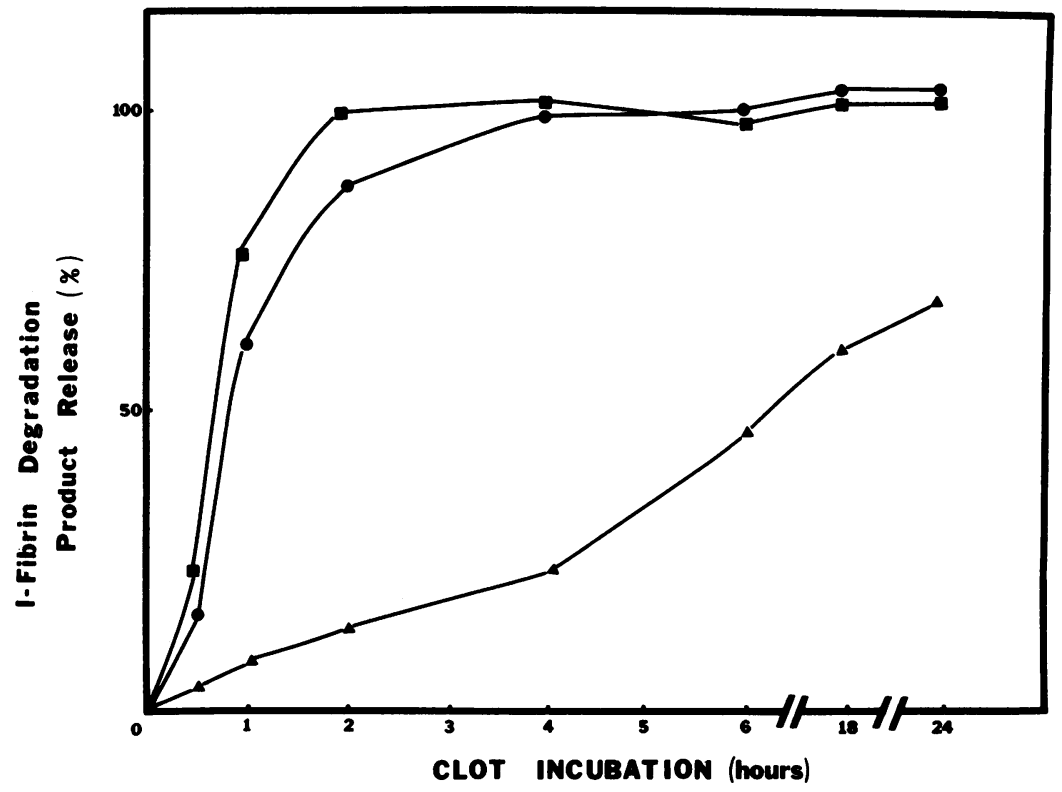

Figure 4 Effect of neutralizing protein $C_{a}$ on the rate of clot lysis. A dog was injected with $5 \mu \mathrm{g}$ protein $C_{a}$ per milliliter plasma volume. Blood was drawn 5 min after protein $C_{a}$ administration and was divided into 2 aliquots. One aliquot had sufficient rabbit IgG directed against protein $\mathrm{C}$ added to neutralize protein $\mathrm{C}_{\mathrm{a}}$ activity $(\odot)$, while the second had the same volume of Tris-saline added (ם). Both samples were clotted, as was a sample of canine blood taken before protein $\mathrm{C}_{\mathrm{a}}$ injection $(\Delta)$. The addition of IgG alone to canine blood did not change the rate of clot lysis (data not shown). Two other animals showed similar results under the same conditions. 
elevated levels in humans with cirrhosis and following venous occlusion and exercise. The levels of lysineadsorbable plasminogen activator were measured before and after protein $\mathrm{C}_{\mathrm{a}}$ administration to a dog (Fig. 5). A fivefold increase in lysine-adsorbable plasminogen activator was observed 5 min after protein $C_{a}$ injection. The lysine-adsorbable plasminogen activator level decreased over the following $30 \mathrm{~min}$. When the equivalent level of protein $C_{a}$ was added to citrated whole blood, no elevation of lysine-adsorbable plasminogen activator was observed.

We wished to determine if a dose-response relationship existed between the level of protein $C_{a}$ administered to the dog and the level of lysineadsorbable plasminogen activation generated, (Fig. 6). A positive dose-response relationship did exist. Within the concentration range tested, the response was not saturated. The highest dose used, $10 \mu \mathrm{g} / \mathrm{ml}$, resulted in the complete lysis of the clots in 25-30 min and a 4.8-fold rise in the plasminogen-activator level.

Whereas the increase in lysine-adsorbable plasminogen activator following protein $\mathrm{C}_{\mathrm{a}}$ administration suggested that this plasminogen activator might be involved in the increased rate of clot lysis observed, any number of other plasminogen activators or profibrinolytic activities might also be generated by the protein $\mathrm{C}_{\mathrm{a}}$. To determine if the levels of lysine-adsorbable plasminogen activator we observed were sufficient to give these increases in the rate of clot lysis, concentrated lysine-adsorbable plasminogen activator (made from the plasma of a dog infused with protein $\mathrm{C}_{\mathrm{a}}$ ) was added to normal canine blood in vitro before clot

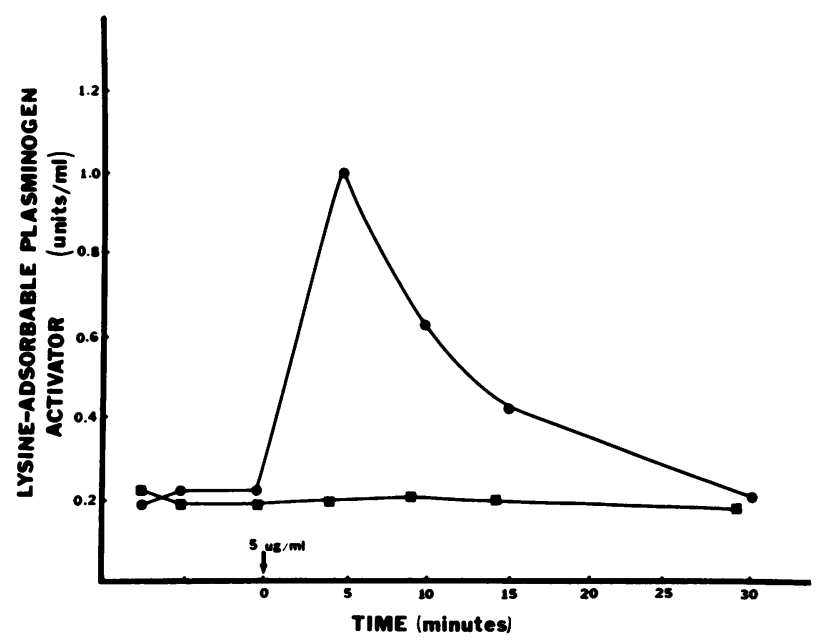

FIgure 5 Change in lysine-adsorbable plasminogen activator activity after protein $\mathrm{C}_{\mathrm{a}}$ addition in vivo and in vitro. At time $0,5 \mu \mathrm{g}$ protein $C_{a}$ per milliliter was injected into a $\operatorname{dog}(0)$ and the levels of lysine-adsorbable plasminogen activator measured at times up to $30 \mathrm{~min}$. The same level of protein $\mathbf{C}_{\mathrm{a}}$ was added to citrated canine blood $(\square)$ and lysine-adsorbable plasminogen activator assayed at the times indicated. Similar results were obtained with three other dogs.

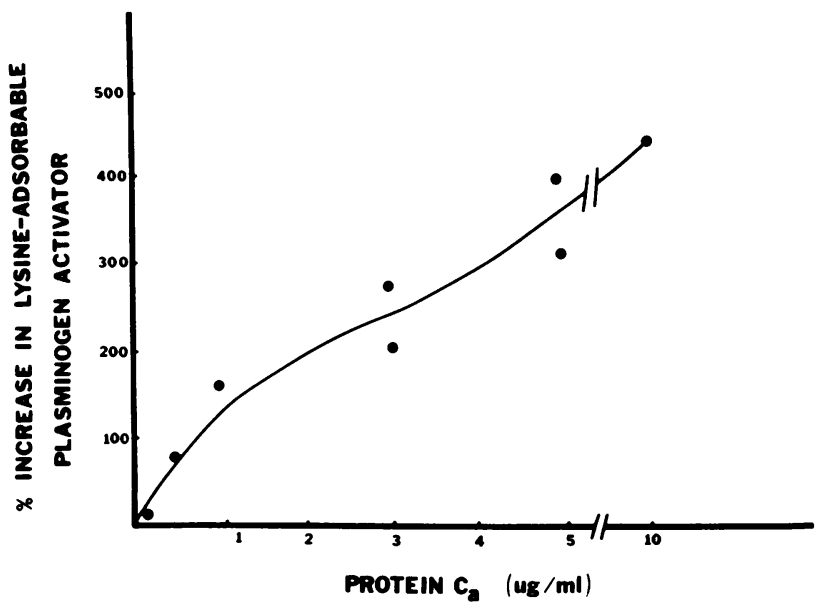

FIGURE 6 Relationship between level of protein $C_{a}$ administered and lysine-adsorbable plasminogen activator level generated. A single dog was administered increasing doses of protein $C_{a}$, ranging from 0.1 to $10 \mu \mathrm{g}$ protein $C_{a}$ per milliliter plasma volume on 8 different $d$. The plasminogen activator levels were measured before and 5 min after protein $C_{a}$, and the percentage increase in plasminogen activator was plotted as a function of protein $\mathrm{C}_{\mathrm{a}}$ dose administered. Similar changes in plasminogen activator levels following protein $C_{a}$ infusion were observed in four other dogs.

formation (Fig. 7). The canine blood had $0.06 \mathrm{U}$ intrinsic activator activity per milliliter and had a relatively slow rate of fibrin-split product release. Lysineadsorbable plasminogen activator was added to the blood at levels approximating those seen after protein $\mathrm{C}_{\mathrm{a}}$ infusion. The exogenous plasminogen activator produced whole blood clot lysis rates in vitro comparable to those observed following protein $C_{a}$ administration in vivo.

Estimation of molecular weight of plasminogen activator by SDS gel electrophoresis. Lysine-adsorbable plasminogen activator was obtained from plasma samples prepared before and after injection of 3 $\mu \mathrm{g}$ protein $\mathrm{C}_{\mathrm{a}}$ per milliliter canine plasma volume. The molecular weight of the plasminogen activator was determined on SDS gels as described (Methods). The molecular weight was estimated at 70,000-72,000 (Fig. $8)$. This value was in agreement with estimates made using Ultrogel AcA34 of 62,000-66,000.

Neutralization of protein $C_{a}$ added to blood in vitro. The generation of plasminogen activator could be due to either a direct or indirect effect of protein $\mathrm{C}_{a}$ on plasminogen activator production. The indirect mechanism could involve formation of a product in blood, which then leads to the release/generation of plasminogen activator. To examine the latter possibility, we added protein $\mathrm{C}_{\mathrm{a}}$ to blood in vitro and then neutralized the protein $C_{a}$ with antibodies before reinjection into the dog (Fig. 9). Although the protein $\mathrm{C}_{\mathrm{a}}$ activity was neutralized by the IgG, an increase in the rate of lysis occurred, and a $290 \%$ increase in 


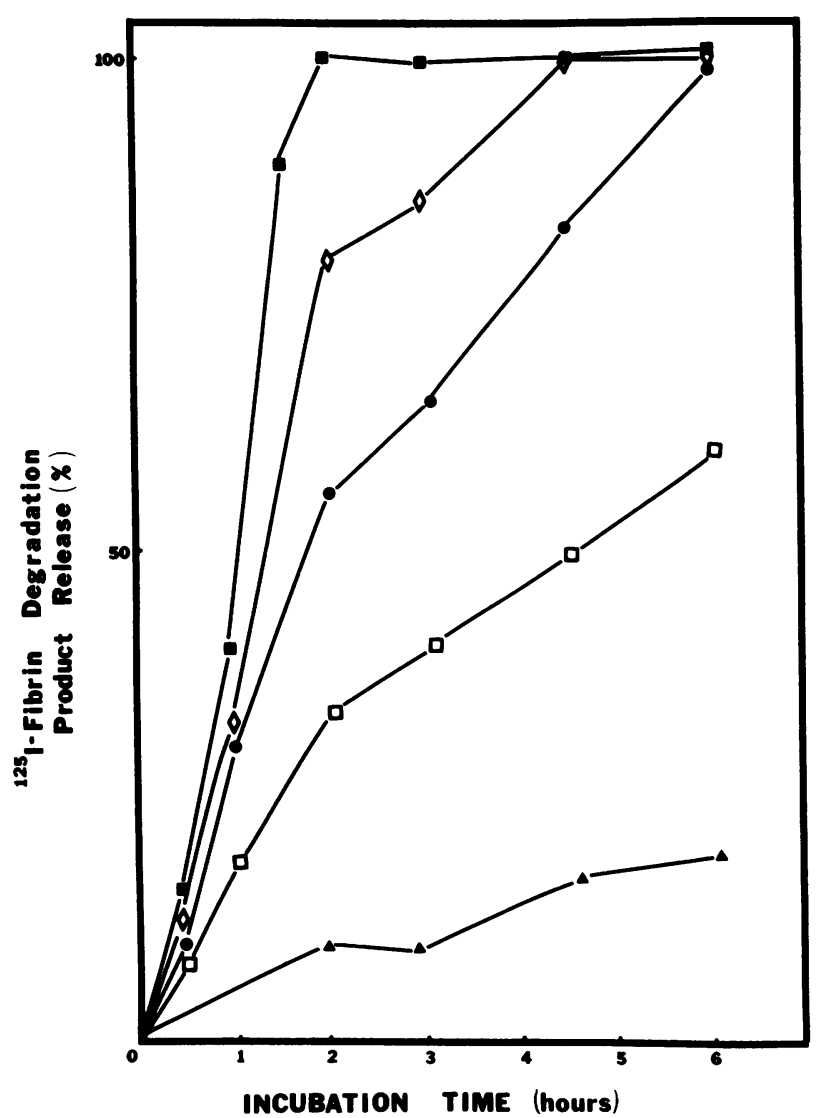

FIGURE 7 Effect on clot lysis of supplementation of normal canine blood with concentrated lysine-adsorbable plasminogen activator. Citrated whole blood from a donor dog was supplemented with concentrated plasminogen activator. The citrated donor canine blood $(\boldsymbol{\Delta})$ that did not have additional plasminogen activator added had $0.06 \mathrm{U}$ lysine-adsorbable plasminogen activator per milliliter. The blood was supplemented by adding plasminogen activator to final concentrations of $0.13 \mathrm{U} / \mathrm{ml}(\square), 0.20 \mathrm{U} / \mathrm{ml}(\odot), 0.27 \mathrm{U} / \mathrm{ml}(\diamond)$, and 0.34 $\mathrm{U} / \mathrm{ml}(\square)$. The citrated blood samples were clotted and the release of ${ }^{125} \mathrm{I}$-fibrin-split products deterined. Two duplicate experiments using blood from two other dogs gave comparable results.

plasminogen activator level was observed. When the protein $\mathrm{C}_{\mathrm{a}}$ was neutralized with IgG before addition to the blood, no increase in the rate of lysis and no increase in plasminogen activator occurred. These results suggest that the protein $\mathrm{C}_{\mathrm{a}}$ generates a secondary messenger in blood, which in turn is involved in the appearance of plasminogen activator and the increased rate of clot lysis.

To investigate which components of blood were necessary to generate the secondary messenger, protein $\mathrm{C}_{\mathrm{a}}$ was added in vitro to washed blood cells alone, plasma alone, and to recombined plasma and blood cells. The protein $C_{a}$ added in vitro was then neutralized with antiprotein $\mathrm{C}$ antibodies and the supernate from the cells, the plasma and supernate from the recombined cells plus plasma were sequentially

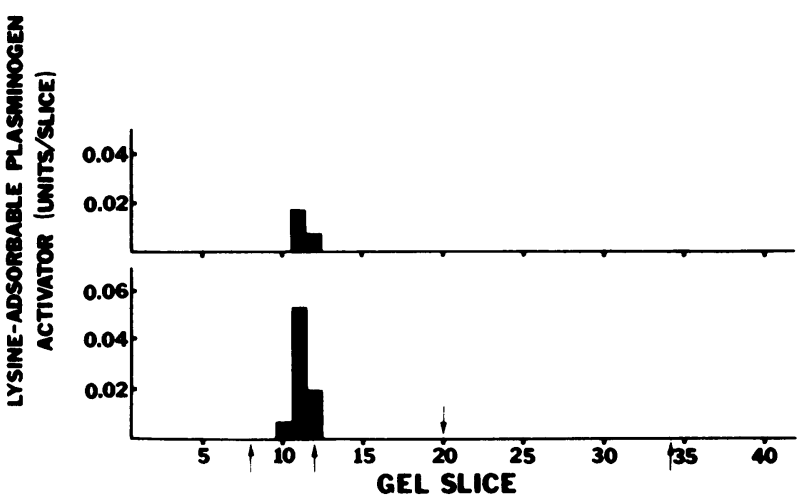

FIGURE 8 Estimation of the molecular weight of plasminogen activator. Lysine-adsorbable plasminogen activator was prepared from plasma samples taken before and after infusion of $3 \mu \mathrm{g} / \mathrm{ml}$ protein $\mathrm{C}_{\mathrm{a}}$ into the dog. Samples $(200 \mu \mathrm{l})$ were electrophoresed on $10 \%$ polyacrylamide gels in SDS as described (Methods). (Top panel-before infusion; bottom panel-postinfusion). Molecular weight markers (indicated by arrows from left to right) were phosphorylase $B$, bovine serum albumin, ovalbumin, and chymotrypsinogen. Plasminogen activator activity was measured as described in Methods. Urokinase was used to construct a standard curve.

injected into the $\operatorname{dog}$ (Fig. 10). The washed cell supernate did not increase fibrinolytic activity. The administration of protein $\mathrm{C}_{\mathrm{a}}$-treated plasma resulted in a

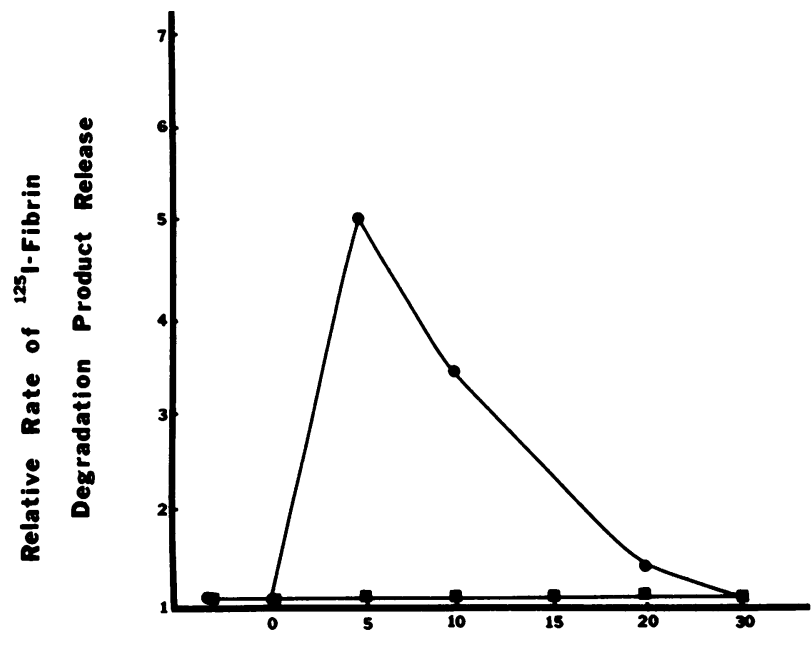

TIME AFTER PLASMA MuECTION (minutes)

Figure 9 Treatment of blood in vitro with protein $\mathrm{C}_{\mathrm{a}}$ followed by addition of antiprotein $C$ IgG. Protein $C_{a}$ was added to $50-\mathrm{ml}$ citrated whole blood and incubated for $5 \mathrm{~min}$ at $37^{\circ} \mathrm{C}$. The blood cells were precipitated by centrifugation for $10 \mathrm{~min}$ at $1,000 \mathrm{~g}$ and sufficient antiprotein $\mathrm{C} \mathrm{IgG}(1.9 \mathrm{ml})$ was added to the $28 \mathrm{ml}$ of resulting plasma to inhibit the protein $\mathrm{C}_{\mathrm{a}}$. The plasma was incubated 5 more min at $25^{\circ} \mathrm{C}$ and then injected into the dog and the relative rate of clot lysis recorded before and after plasma administration ( $\odot$ ). A control was also run which consisted of mixing the same amounts of protein $C_{a}$ and antiprotein C IgG together for 5 min before adding the mixture to the same volume of blood $(\square)$ and injecting the plasma into the animal. Similar results were obtained using two other animals. 


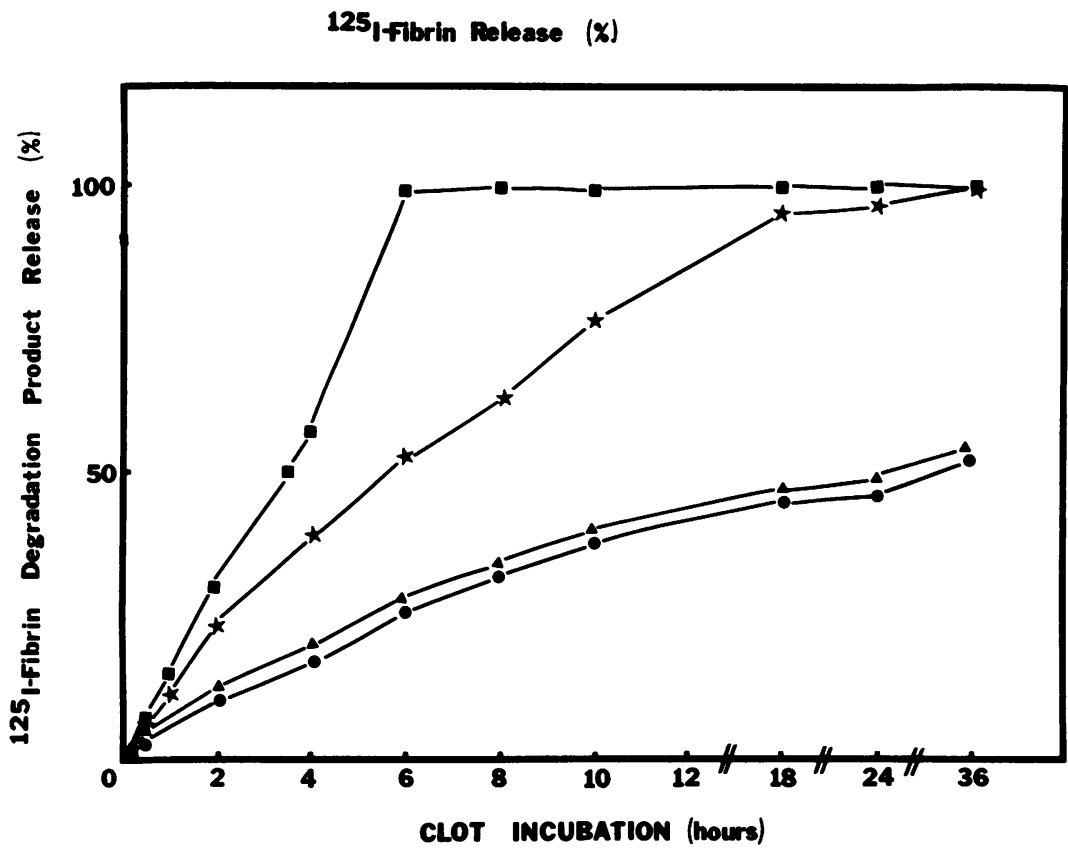

Figure 10 Treatment of washed cells, plasma, and whole blood in vitro with protein $\mathrm{C}_{\mathrm{a}}$. Protein $\mathrm{C}_{\mathrm{a}}(3 \mu \mathrm{g} / \mathrm{ml}$ fluid volume) was added to $50 \mathrm{ml}$ washed blood cells, $50 \mathrm{ml}$ citrated plasma, and to recombined washed blood cells and plasma. The three fractions were incubated for $5 \mathrm{~min}$ at $37^{\circ} \mathrm{C}$ and then centrifuged at $1,000 \mathrm{~g}$ for $10 \mathrm{~min}$. The supernates were collected and sufficient antiprotein $C$ antibodies were added to neutralize protein $C_{a}$ activity. The three supernatants were then injected intravenously into the dog at 30 -min intervals. Addition of protein $C_{a}$ in vitro was timed to precede injection by $20 \mathrm{~min}$ for each sample. Order of addition was $(a)$ supernate from washed cells $(\boldsymbol{\Delta}),(b)$ plasma $(\star)$, and $(c)$ supernate from recombined cells and plasma $(\square)$. Blood drawn before the injections was also assayed (๑). A duplicate experiment in another animal gave similar results.

6.5-fold increase in the rate of fibrin degradation product release. The infusion of the supernate from the protein $\mathrm{C}_{\mathrm{a}}$-treated recombined cells and plasma yielded a 10.3-fold increase in fibrinolytic activity. Although addition of protein $\mathrm{C}_{\mathrm{a}}$ to the cells did not result in increased fibrinolytic activity, the cells did augment the effect seen by adding protein $C_{a}$ to plasma alone.

\section{DISCUSSION}

The in vivo administration of physiologic levels of activated protein $C$ causes a dramatic increase in the rate of whole blood clot lysis. The fibrinolytic response to activated protein $\mathrm{C}$ is specific; class-similar proteins such as prothrombin do not enhance the rate of clot lysis. The active site of protein $C_{a}$ is necessary for the enhancement of clot lysis because neither diisopropylfluorophosphate-inhibited protein $C_{a}$ nor the zymogen protein $\mathrm{C}$ enhance clot lysis. This enhanced ability to lyse clots formed in vitro appears to result primarily from an elevation of circulating plasminogen activator levels. When lysine-adsorbable plasminogen activator is added to normal blood in vitro to elevate the plasminogen activator levels to those seen in vivo following protein $C_{a}$ infusion, the rate of clot lysis of the supplemented blood is similar to that of the blood taken from animals receiving protein $\mathrm{C}_{\mathrm{a}}$. Whereas other plasma proteins may contribute to the increased rate of clot lysis, the rise in the levels of this plasminogen activator are sufficient to cause the increase in lytic activity. The plasminogen activator does not cause intravascular fibrinogenolysis, as evidenced by normal levels of plasminogen and no elevation of fibrinogen degradation products during prolonged infusions of protein $\mathrm{C}_{\mathrm{a}}$. This suggests that the plasminogen activator may function more efficiently in the presence of fibrin in the formed blood clot. This suggests a role of protein $\mathrm{C}_{\mathrm{a}}$ in clot lysis different than either urokinase or streptokinase, both of which activate circulating plasminogen, which subsequently degrades fibrinogen. The thrombolytic effect of protein $C_{a}$ may protect the animals from bleeding episodes during and after protein $C_{a}$ administration. In over 150 protein $C_{a}$ administrations to dogs, none have shown evidence of bleeding and none have died. Following the administration of protein $\mathrm{C}_{\mathrm{a}}$, the effect on clot lysis is of limited duration and the plasminogen activation generated is cleared from the plasma.

The origin of the lysine-adsorbable plasminogen activator is unknown. However, the molecular weight 
of 70,000 suggests it may be related to vascular plasminogen activator described by others $(20,21)$. Vascular plasminogen activator is released into the blood by various physiologic events, including ischemia (22), pyrogenemia (23), and physical exercise (24). The administration of protein $C_{a}$ causes the elevation of plasminogen activator activity without changing the animals' pulse, respiratory rate, blood pressure, or temperature. Therefore, it is doubtful hypotension or shock play a role in the action of protein $\mathrm{C}_{\mathrm{a}}$.

Protein $\mathrm{C}_{\mathrm{a}}$ does not appear to directly release plasminogen activator from the vasculature. Our preliminary results indicate that when oxygenated buffer containing protein $\mathrm{C}_{\mathrm{a}}$ is used to perfuse isolated dog tissues, little or no plasminogen activator activity is released from the blood vessel walls. However, when protein $\mathrm{C}_{\mathrm{a}}$ is added to blood in vitro with subsequent neutralization of the protein $C_{a}$ with antibodies, the rate of clot lysis is increased when the blood is reinjected into the animal. The addition of protein $\mathrm{C}_{\mathrm{a}}$ to plasma alone is sufficient to generate the fibrinolytic activity, but the effect is more marked when protein $\mathbf{C}_{\mathbf{a}}$ is added to a mixture of plasma and blood cells. These findings suggest that protein $\mathrm{C}_{\mathrm{a}}$ generates a secondary messenger, or family of messengers, which in turn cause the elevation of circulating plasminogen activator activity.

\section{ACKNOWLEDGMENTS}

The authors wish to thank Paul Wong for his skillful assistance. The work of René Jacocks and Ted Mickel is also appreciated. We also appreciate the assistance of Penny Barnett and Barbara Irish in the preparation of the manuscript.

This work was supported by grant HL17812 from the National Heart and Lung Institute and performed during the tenure of Dr. Esmon's Established Investigatorship of the American Heart Association with funds contributed in part by the Oklahoma Affiliate.

\section{REFERENCES}

1. Kisiel, W., W. M. Canfield, L. H. Ericsson, and E. W. Davie. 1977. Anticoagulant properties of bovine protein C following activation by thrombin. Biochemistry. 16: 5824-5831.

2. Vehar, G. A., and E. W. Davie. 1980. Preparation and properties of bovine factor VIII. Biochemistry. 19: 401-410.

3. Kisiel, W., L. H. Ericsson, and E. W. Davie. 1976. Proteolytic activation of protein $\mathrm{C}$ from bovine plasma. Biochemistry. 15: 4893-4900.

4. Marlar, R. A., and J. H. Griffin. 1980. Deficiency of protein $\mathrm{C}$ inhibitor in combined factor V/VIII deficiency disease. J. Clin. Invest. 66: 1186-1189.

5. Esmon, C. T., and W. G. Owen. 1981. Identification of an endothelial cell cofactor for thrombin-catalyzed activation of protein C. Proc. Natl. Acad.Sci.U.S. A. 78: 2249-2252.

6. Owen, W. G., and C. T. Esmon. 1981. Functional properties of an endothelial cell cofactor for thrombin-catalyzed activation of protein C. J. Biol. Chem. 256: 5532-5535.
7. Seegers, W. H., L. E. McCoy, H. D. Groben, N. Sakuragawa, and B. L. Agrawal. 1972. Purification and some properties of autoprothrombin II-A; an anticoagulant perhaps also related to fibrinolysis. Thromb. Res. 1: 443-460.

8. Zolton, R. P., and W. H. Seegers. 1973. Autoprothrombin II-A: thrombin removal and mechanism of induction of fibrinolysis. Thromb. Res. 3: 23-33.

9. Comp, P. C., and C. T. Esmon. 1980. Evidence for multiple roles for activated protein $\mathrm{C}$ in fibrinolysis. In The Regulation of Coagulation. K. G. Mann and F. B. Taylor, Jr., editors. Elsevier North-Holland, Inc. 583588.

10. Comp, P. C., R. M. Jacocks, C. Rubenstein, and R. Radcliffe. 1981. A specific circulating plasminogen activator, or class of activators, is elevated in conditions associated with increased fibrinolytic activity. J. Lab. Clin. Med. 97: 637-649.

11. Deutsch, D. G., and E. T. Mertz. 1970. Plasminogen: purification from human plasma by affinity chromatography. Science (Wash. D. C.). 170: 1095-1097.

12. Fujikawa, K., A. R. Thompson, M. E. Legaz, R. G. Meyer, and E. W. Davie. 1973. Isolation and characterization of bovine factor IX. Biochemistry. 12: 49384945.

13. Cuatrecasas, P. 1970. Protein purification by affinity chromatography, derivations of agarose and polyacrylamide beads. J. Biol. Chem. 245: 3059-3072.

14. Walker, F. J., P. W. Sexton, and C. T. Esmon. 1979. The inhibition of blood coagulation by activated protein $\mathrm{C}$ through selective inactivation of activated factor $\mathrm{V}$. Biochim. Biophys. Acta. 571: 333-342.

15. Stenflo, J. 1976. A new vitamin K-dependent protein: purification from bovine plasma and preliminary characterization. J. Biol. Chem. 251: 355-363.

16. Owen, W. G., C. T. Esmon, and C. M. Jackson. 1974. The conversion of prothrombin to thrombin. I. Characterization of the reaction products formed during activation of bovine prothrombin. J. Biol. Chem. 249: 594-603.

17. Comp, P. C., and C. T. Esmon. 1979. Activated protein C inhibits platelet prothrombin converting activity. Blood. 54: 1272-1281.

18. Laemmli, V. K. 1970. Cleavage of structural proteins during assembly of head bacteriophage T4. Nature (Lond.). 227: 680-685.

19. Radcliffe, R., and T. Heinze. 1978. Isolation of plasminogen activator from human plasma by chromatography on lysine-sepharose.Arch. Biochem. Biophys. 189: 185-197.

20. Rijken, D. C., G. Wijngaards, M. Zaal De Jong., and J. Welbergen. 1979. Purification and partial characterization of plasminogen activator from human uterine tissue. Biochim. Biophys. Acta. 580: 140-153.

21. Binder, B. R., J. Spragg, and K. F. Austen. 1979. Purification and characterization of human vascular plasminogen activator derived from blood vessel perfusates. J. Biol. Chem. 254: 1998-2003.

22. Nilsson, I. M. 1975. Phenformin and ethylestrenol in recurrent venous thrombosis. In Progress in Chemical Fibrinolysis and Thrombolysis. J. F. Davidson, M. M. Samama, and P. C. Desnoyers, editors. Raven Press, New York. 1: 1-12.

23. Sawyer, W. D., A. P. Fletcher, N. Alkjaersig, and S. Sherry. 1960. Studies on the thrombolytic activity of human plasma. J. Clin. Invest. 39: 426-434.

24. Cash, J. D. 1966. Effect of moderate exercise on the fibrinolytic system in normal young men and women. Br. Med.J. 2: 502-506. 